\title{
A retroperitoneal mass confirmed as a pancreatic adenosquamous carcinoma by endoscopic ultrasound-guided fine-needle aspiration
}

Adenosquamous carcinoma is a rare subtype of pancreatic adenocarcinoma, accounting for less than $4 \%$ of all exocrine pancreatic malignancies and representing a ductal adenocarcinoma mixed with at least $30 \%$ of malignant squamous cells [1 -3]. Herein, we report a patient with a retroperitoneal mass in whom endoscopic ultrasound-guided fine-needle aspiration (EUS-FNA) and immunohistochemical evaluation confirmed a pancreatic adenosquamous carcinoma ( $\vee$ Video 1$)$.

A 65-year-old white man with epigastric pain and weight loss was referred for investigation of a pancreatic mass detected on abdominal computed tomography. Results of clinical laboratory examinations were unremarkable. Sectorial endoscopic ultrasound (Olympus GF-UCT140AL5 [Olympus America Inc., New York, USA], coupled to an ultrasound unit Aloka ProSound alpha-5 SX) detected a solid lesion with irregular borders measuring $4.9 \times 3.5 \mathrm{~cm}$ in the pancreatic body. EUSFNA was performed via a transgastric approach using a 19-gauge needle (EchoTip Ultra Echo-19; Cook Medical, Winston-Salem, North Carolina, USA) for a total of three passes. There was no on-site cytopathologist. Histopathology on cell blocks demonstrated a mixture of adenocarcinoma cells with malignant squamous epithelium. Immunohistochemistry panel was positive for S100 p, cytokeratin 7 (both markers of glandular differentiation), p63, and cytokeratin 5/6 (both markers of squamous epithelium),

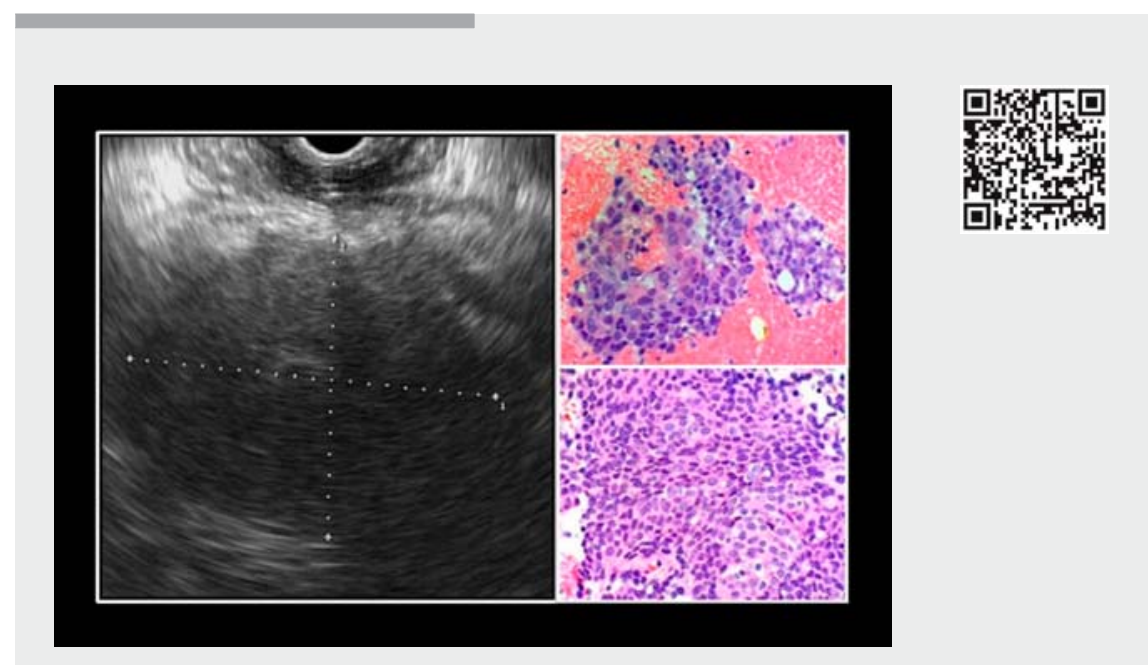

Video 1 Adenosquamous carcinoma is an aggressive subtype of adenocarcinoma, accounting for less than $4 \%$ of all exocrine pancreatic malignancies. Endoscopic ultrasoundguided fine-needle aspiration can guarantee the diagnosis in the presence of a ductal adenocarcinoma mixed with malignant squamous cell carcinoma and specific immunohistochemical markers.

but negative for chromogranin A and mucin 5AC.

Optimal treatment remains undefined for the disease. The patient was offered chemotherapy with gemcitabine. After two cycles, liver metastases were detected. A new chemotherapy protocol was begun with oxaliplatin, folinic acid, and fluorouracil. There was no response and the patient died 6 months later.

Endoscopy_UCTN_Code_CCL_1AF_2AZ_3AB

\section{Competing interests}

None

The authors

César Vivian Lopes ${ }^{1}$, Antônio Dal Pizzol Júnior ${ }^{2}$, Karen Margarita Rico Escamilla ${ }^{3}$, Antônio Atalíbio Hartmann ${ }^{3}$

1 Department of Gastroenterology and Digestive Endoscopy, Santa Casa Hospital, Porto Alegre, Brazil

2 Department of Clinical Oncology, Santa Casa Hospital, Porto Alegre, Brazil

3 Department of Pathology, Santa Casa Hospital, Porto Alegre, Brazil 


\section{Corresponding author}

\section{César Vivian Lopes, MD}

Rua Prof. Cristiano Fischer 668/1001, C.E.P. 91.410-000 Porto Alegre-RS, Brazil

Fax: +55-51-33388054

drcvlopes@gmail.com

\section{References}

[1] Boyd CA, Benarroch-Gampel ], Sheffield KM et al. 415 patients with adenosquamous carcinoma of the pancreas: a populationbased analysis of prognosis and survival. J Surg Res 2012; 174: 12 - 19
[2] Kardon DE, Thompson LD, Przygodzki RM et al. Adenosquamous carcinoma of the pancreas: a clinicopathologic series of 25 cases. Mod Pathol 2001; 14: 443-451

[3] Borazanci E, Millis SZ, Korn R et al. Adenosquamous carcinoma of the pancreas: molecular characterization of 23 patients along with a literature review. World J Gastrointest Oncol 2015; 7: $132-140$

\section{Bibliography}

DOI https://doi.org/10.1055/s-0043-120519

Published online: 25.10.2017

Endoscopy 2018; 50: E13-E14

(c) Georg Thieme Verlag KG

Stuttgart · New York

ISSN 0013-726X

\section{ENDOSCOPY E-VIDEOS}

https://eref.thieme.de/e-videos

回回 Endoscopy E-Videos is a free access online section, reporting 靣: on interesting cases and new techniques in gastroenterological endoscopy. All papers include a high quality video and all contributions are freely accessible online.

This section has its own submission website at

https://mc.manuscriptcentral.com/e-videos 